\title{
A comparative analysis of citizens' eco-awareness between Toyota City in Japan and Neiva City in Colombia
}

\author{
Hiroshi Ito, ${ }^{1,}$, Paola Tafur ${ }^{2}$ \\ ${ }^{1}$ Faculty of Economics, Nagoya University of Commerce and Business, Nisshin City, Japan \\ ${ }^{2}$ Department of Political Science, Universidad de Surcolombiano, Neiva, Colombia
}

\section{Email address:}

hito@nucba.ac.jp (H. Ito), m.paolatafur@gmail.com (P. Tafur)

\section{To cite this article:}

Hiroshi Ito, Paola Tafur. A Comparative Analysis of Citizens' Eco-Awareness between Toyota City in Japan and Neiva City in Colombia. International Journal of Environmental Protection and Policy. Vol. 2, No. 6, 2014, pp. 218-223. doi: 10.11648/j.ijepp.20140206.14

\begin{abstract}
This paper analyzes citizens' eco-awareness between Toyota City in Japan and Neiva City in Colombia. Both cities have been making efforts to promote their eco-policies, which are somewhat similar to each other in areas such as transportation and public welfare and livelihood. To put these policies into practice, civic support is essential. Through survey questionnaires, this study compares citizens' awareness of eco-policies in Toyota City and Neiva City. Findings show that Toyota City outperforms Neiva City in some areas such as forests and the urban center while Neiva outperforms in other areas: transportation and industry. This paper explains possible reasons for these differences and makes suggestions to further promote eco-policies.
\end{abstract}

Keywords: Eco-Policy, Environmental Assessment, Comparative Analysis

\section{Introduction}

Toyota City is located in Aichi, Japan. Its economy relies largely on the automobile industry as the city is the headquarters of the Toyota Motor Corporation. Environmental protection has inevitably become a concern due to the characteristics of the principle economic activity: the city has long been working on addressing environmental issues. In the mid-1990s, the city implemented action plans for environmental protection, which were further developed in the beginning of the 2000s. In 2009, the city was designated as one of the environmental model cities working toward low-carbon society by Japan's Ministry of Environment [1]. The city has promoted its eco-policy based on five strategic themes: transportation, forests, the urban center, industry, and public welfare and livelihood [2].

Neiva City is located in Huila, Colombia. Principal economic activities are agriculture and producing and exporting agricultural products such as coffee and cotton. The city also exploits petroleum and natural gas resources. As is the case with Toyota City, Neiva City has promoted an environmental policy, called ordenanza (ordinance) No. 37, which was enacted in 2013. It aims to improve the quality of citizens' lives through the conservation, restoration, management, and sustainable use of environmental resources.

In order to materialize environmental policies into practices, citizens play a significant role due to their "direct contribution to ecological impacts and influence on local socio-economic actors" [3]. Therefore, it is important for citizens to recognize their cities' eco-policies.

It remains, however, unclear whether Toyota City and Neiva City promote their eco-policies well. How much are Toyota and Neiva citizens aware of their cities' eco-policies? Does there exist any difference in the level of citizens' eco-awareness between Toyota City and Neiva City? If so, what are possible reasons for the difference? Given their relatively similar eco-policies, is there something that Toyota City and Neiva City can learn from each other to promote eco-policies? In order to answer these research questions, this study first measures citizens' eco-awareness in each city through survey questionnaires. Next, it examines possible reasons to explain different levels of citizens' eco-awareness between the two cities. Based on findings, this study makes some suggestions to further promote eco-policies.

\section{Toyota and Neiva Cities' Eco-Policies}

Toyota City's eco-policy comprises five themes: transportation, forest, the urban center, industry, and public welfare and livelihood [2]. Neiva City has a comprehensive eco-policy that is somewhat similar to that of Toyota City. As explained in the following sub-sections, both cities have been 
working on specific policies and strategies related to transportation, the urban center, and social welfare and livelihood. This section reviews how Toyota City and Neiva City have been materializing their eco-policies in the context of the above-stated five themes.

\subsection{Transportation}

Regarding transportation, Toyota City has promoted an environmentally friendly public transportation system called the Ha:mo - a new urban transport support system with NAVI (i.e., an information system that supports low-carbon and seamless mobility) and RIDE (i.e., a car sharing system that uses compact electric vehicles such as Comus and iRoad for urban short-distance transportation) [4].

In Neiva City, future plans are being developed by the local government for a public transportation system called "Tierra de Promisión" (Promised Land). This initiative was adopted through the city's Decree 0948 in 2013 . This project aims to streamline and modernize the city's streets along with upgrading to the latest environmentally friendly motor vehicle technology in order to improve citizens' mobility and transport [5].

\subsection{Urban Center}

Toyota City has been working toward greening at least $10 \%$ of the land cover where $60 \%$ of the land property is occupied by buildings and preferably $20 \%$ where $80 \%$ of is occupied by buildings in its urban center. This works against the heat-island effect - urban areas experiencing elevated temperatures [6]. Toyota City has been using rooftop and wall greening, environmentally friendly parking, and water-retentive pavement to achieve the city's goals.

Neiva City has recently implemented the "plan ornato" (beautiful plan), which involves the recovery of parks and recreational areas in order to green the city and fight the effects of global warming. This environmental initiative also ensures a cleaning process of the sediment and residues in the main existing waterways. The city designated $335 \mathrm{~km}^{2}$ of its total $1,250 \mathrm{~km}^{2}$ (approximately $26.8 \%$ of the surface) as protected areas [7][8][9].

\subsection{Welfare and Livelihood}

Toyota City promotes the Smart House, which automatically controls and monitors energy production and consumption at home [10]. The Smart House principally generates energy by solar panels built on the roof and can store the energy in a home storage battery or even on-board batteries equipped in electronic vehicles (EVs). An EV battery can store up to a few days of electric energy for home usage [11]. Citizens can also sell excess energy to City Hall or Electric Power Companies.

In Colombia, in accordance with the law 388 of 1997 and in line with other national standards, energy-efficient housing is considered a determining factor for the assessment of performance of environmental policies that address the current needs of the country. However, such national legal provisions in Neiva City have not been regulated normatively; thus the construction of energy efficient housing is carried out by business initiatives of the private agenda (Armando Losada, the co-founder and the design coordinator of Centro de Energías Alternativas [CEA-COL: Alternative Energy Center], personal communication, September 24, 2014).

\subsection{Industry}

Toyota City promotes sustainable plants - factories with systems for creating, storing, and economizing energy. According to [12], sustainable plants lead to environmental performance and increase the use of renewable energy in harmony with natural surroundings. In order to develop sustainable plants in Japan, the Toyota Motor Corporation addresses the issues of: 1) reducing $\mathrm{CO}_{2}$ emissions by increasing renewable energy sources, 2) protecting the environment by inspiring members to take action and encouraging and engaging the local community to preserve and promote the local ecosystem, and 3) realizing excellent environmental performance by introducing and improving advanced technology [12].

In Neiva City, there exist various private entrepreneurship initiatives such as CEA-COL, which aim to provide, advise, and encourage the use of new technologies for energy generation. Providing alternatives fills with high technological content in response to the rising energy demands, environmental conservation, ecological organization, and civic empowerment through technology (Armando Losada, personal communication, September 24, 2014).

\subsection{Forests}

According to [13], about $70 \%$ of the city is wooded. In order to maintain forests in decent conditions, the city promotes periodic thinning, or kanbatsu, by removing trees from the condensed woods to make room for other trees to grow [14]. This makes it possible to maximize $\mathrm{CO} 2$ absorption [15].

Neiva City aims to collaborate with civil society in the conservation of forest areas. The Ministry of Municipal Finance offers tax benefits (i.e., discount on payment of property tax in proportion to the space of the property intended for preservation) to the owners of properties in rural areas. In addition, the Ministry of Municipal Environment is responsible for issuing the technical specifications of the areas planned for environmental conservation, which by 2014 reached $75,061 \mathrm{~km}^{2}$ [16].

\section{Methodology}

In order to examine citizens' eco-awareness of both cities, survey questionnaires were conducted in Toyota City in June 2014 and Neiva City in July 2014. The number of valid respondents was 247 and 300 respectively. For Toyota City, 28 third and fourth year students at the Nagoya University of Commerce and Business helped conduct the research. For Neiva City, four second year students from the University of 
Surcolombiano helped. Despite some similarities, Toyota's and Neiva's eco-policies are not the same. Therefore, respondents in the cities were asked relevant questions adjusted to each city's specific policies. These questions maintained a connection in that they were made with consideration of Toyota City's five themes: transportation, forests, urban center, industry, and public welfare and livelihood.

With regard to general information about public awareness of Toyota City's eco-policy, Toyota City's questionnaire asked citizens whether they knew that Toyota City was selected as an environmental model city. Citizens in Neiva City were asked whether they knew that there exist the environmental policy approved through ordenanza (ordinance) No. 037 of 2013.

As to transportation, Toyota City's questionnaire asked citizens whether they considered buying a next generation vehicle such as an EV or a PHV, automobiles essential for the establishment of energy efficient transportation system. Neiva City's questionnaire asked citizens whether they considered buying a car that is environmentally friendly. While there exist EVs/PHVs in Colombia, they are not very popular yet [17][18]. That is why, we simply asked them about their willingness to buy eco-friendly cars instead of EVs/PHVs.

Concerning forests, Toyota City's questionnaire asked citizens whether they knew about kanbatsu and its effectiveness for $\mathrm{CO} 2$ reduction. Neiva City's questionnaire asked citizens whether they knew that the city could acquire land properties for the recovery of forests.

As for the urban center, Toyota City's questionnaire asked citizens whether they knew about the heat-island phenomena. Neiva City's questionnaire asked citizens whether they knew about projects to reduce greenhouse gas emissions in Huila.
Regarding industry, Toyota City's questionnaire asked citizens whether they knew that small/medium size companies (SMCs) are working on sustainable plants. Neiva City's questionnaire asked citizens whether they knew that SMCs by law should promote and finance the initiatives of sustainable plants and products to reduce $\mathrm{CO} 2$ in Huila.

With regard to public welfare and livelihood, Toyota City's questionnaire asked citizens whether they knew about the Smart House. Neiva City's questionnaire asked citizens whether they knew about buildings with solar panels for the production of renewable energy.

\section{Results}

Table 1. Personal Information: Age and sex.

\begin{tabular}{lll}
\hline Age & Toyota & Neiva \\
\hline$<19$ & $121(49.0 \%)$ & $68(22.7 \%)$ \\
$20-29$ & $26(10.5 \%)$ & $118(39.3 \%)$ \\
$30-39$ & $24(9.7 \%)$ & $41(13.7 \%)$ \\
$40-49$ & $23(9.3 \%)$ & $30(10.0 \%)$ \\
$>50$ & $53(21.5 \%)$ & $43(14.3 \%)$ \\
Sex & Toyota & Neiva \\
Male & $128(51.8 \%)$ & $143(47.7 \%)$ \\
Female & $119(48.2 \%)$ & $157(52.3 \%)$ \\
Total Respondents & 247 & 300 \\
\hline
\end{tabular}

Table 2. Personal Information: Age and sex.

\begin{tabular}{lll}
\hline & Toyota & Neiva \\
\hline Recognition of the cities' eco-policies & & \\
Yes & $83(34.2 \%)$ & $60(20.0 \%)$ \\
No & $160(65.8 \%)$ & $240(80.0 \%)$ \\
Unanswered & 4 & 0 \\
\hline
\end{tabular}

Table 3. Specific information about citizens'eco-awareness.

\begin{tabular}{|c|c|c|}
\hline Transportation & Toyota & Neiva \\
\hline \multicolumn{3}{|c|}{ Are you considering buying a next generation vehicle? Do you consider buying a car that is environmentally friendly? } \\
\hline Yes & $98(40.0 \%)$ & $276(92.0 \%)$ \\
\hline No & $147(60.0 \%)$ & $24(8.0 \%)$ \\
\hline Unanswered & 2 & 0 \\
\hline Forests & Toyota & Neiva \\
\hline \multicolumn{3}{|c|}{ Do you know kanbatsu effective for $\mathrm{CO} 2$ reduction? Do you know the city could acquire land properties for the recovery of forests? } \\
\hline Yes & $85(34.8 \%)$ & $89(29.7 \%)$ \\
\hline No & $159(65.2 \%)$ & $211(70.3 \%)$ \\
\hline Unanswered & 5 & 0 \\
\hline Urban center & Toyota & Neiva \\
\hline \multicolumn{3}{|c|}{ Do you know about the heat island phenomena? Do you know there exist projects to reduce green gas emissions in Huila? } \\
\hline Yes & $93(38.1 \%)$ & $75(25.0 \%)$ \\
\hline No & $151(61.9 \%)$ & $225(75.0 \%)$ \\
\hline Unanswered & 0 & 0 \\
\hline Industry & Toyota & Neiva \\
\hline \multicolumn{3}{|c|}{$\begin{array}{l}\text { Do you know SMCs are working on sustainable plants? Do you know SMCs by law should promote the initiatives of sustainable plants to reduce CO2 ir } \\
\text { Huila? }\end{array}$} \\
\hline Yes & $48(19.7 \%)$ & $131(43.7 \%)$ \\
\hline No & $196(80.3 \%)$ & $169(56.3 \%)$ \\
\hline Unanswered & 3 & 0 \\
\hline Public welfare and livelihood & Toyota & Neiva \\
\hline \multicolumn{3}{|c|}{ Do you know about the Smart House? Do you know aboutbuildings with solar panels for the production of energy? } \\
\hline Yes & $133(54.5 \%)$ & $40(13.3 \%)$ \\
\hline No & $111(45.5 \%)$ & $260(86.7 \%)$ \\
\hline Unanswered & 3 & 0 \\
\hline
\end{tabular}


Results indicate that Toyota City outperformed Neiva City in general recognition of eco-policy, forests, the urban center, and public welfare and livelihood; however, the difference in recognition of forests between the two cities was not statistically significant while the others were statistically significant $(\mathrm{p}<0.01)$. Neiva City outperformed Toyota City in transportation and industry, both being statistically significant $(p<0.01)$. The following section intends to explain why there exist such differences.

\section{Discussion}

Regarding the general recognition of eco-policy, Toyota City outperformed Neiva City possibly, in part, because Toyota City officially started its eco-policy in 2009 whereas Neiva City initiated its own in 2013. The establishment of Ecoful Town was arguably helpful in promoting Toyota City's eco-policy as well. Toyota City also outperformed Neiva City in forests, but the difference was not statistically significant. Toyota City started working on the issues of forests relatively late. Indeed, in Ecoful Town, a pavilion established in 2012 to demonstrate how Toyota City tackles challenges and elaborates on strategies toward a low-carbon society based on the five themes, the section of forests was built the last in 2014. Concerning the urban center, Toyota City again outperformed Neiva City possibly, in part, because Toyota City's questionnaire asked about the heat-island effect in general while that of Neiva City asked about a specific project (i.e., the Regional Environmental Management Plan). As for public welfare and livelihood, the presence of the Smart House within Ecoful Town located in the city center seems to help the topic's visibility.

In Neiva City, environmental initiatives on transportation and industry are the most recognized due to recent dynamics such as remarkable investment in both the public (e.g., transportation) and private (e.g., industry) sectors, direct intervention in citizens' daily lives, and constant media hype.

Toyota City promotes the city's eco-policy through the following methods:

- Establishment of Ecoful Town in the city center

- Provision of free papers and concept books

- Teaching education for sustainable development in schools

Ecoful Town plays a symbolic role in Toyota City's eco-policy and has arguably contributed to its promotion. Neiva City could set up something similar in the city center. Within the pavilion, several specific theme parks can be established. With Ecoful Town, in the context of public welfare and livelihood, the Smart House was built for citizens to freely enter and learn about its home energy management system (HEMS). The main building is covered with moss to show how the heat-island effect can be addressed.

Provision of periodic free papers that inform how Neiva City addresses environmental issues can also be effective in promoting eco-policy. In Toyota City, over $70 \%$ of the city's households receive them. Concept books about eco-policies also inform citizens, especially children, of environmental protection. While this may be criticized for not being environmentally friendly, it helps raise eco-awareness.

Education for Sustainable Development (ESD) is another important topic. In Toyota City, all fourth graders in primary education visit Ecoful Town before summer break to learn about the city's eco-policy. The city's several large high schools such as Toyota Higashi High School are also involved in ESD as UNESCO's associated schools. Toyota Nishi High School, a Super Science School that intends to train future scientists selected by Japan's Ministry of Education, Culture, Sports, Science, and Technology, also sends students to Ecoful Town to learn about how technologies address environmental issues.

On the other hand, in an effort to promote the Sistema estratégico de Transporte Público (Strategic System of Public Transportation: SETP), Neiva City has implemented a campaign of socialization on the broad parameters of the Transportation Project developed through community councils. In addition, the initiative to modernize transportation systems has become a particularly important topic in the media. The SETP in the city of Neiva is one of the most recent initiatives in urban transportation with high expectations locally, regionally and nationally. (Libardo Olayo Carvajal, Transfederal Manager, responsible for establishing SETP in Neiva, personal communication, September 24, 2014).

Moreover, SMCs in Neiva City are engaged in the installation and maintenance of solar panels for renewable energy. Thereby companies such as CEA-COL become active participants in trade shows, preparation of college students, and advocates increase use of technology to environmental protection. Another factor that has allowed the acute appreciation of environmental initiatives from industry is the attention of mass media because its wide circulation and public influence make these mechanisms more likely to reach local populations. Both the recognition of transportation initiatives and industrial sectors can infer that the academic field has become an effective means for disseminating environmental information (Armando Losada, Electronic Engineer and co-founder of Centre for Alternative Energies Neiva -CEA COL-, personal communication, September 24, 2014).

\section{Conclusion}

This paper has examined citizens' eco-awareness between Toyota City in Japan and Neiva City in Colombia. Findings of this study show that Toyota City outperforms Neiva City in some areas such as forests and the urban center while Neiva City outperforms Toyota City in other areas such as transportation and industry. Toyota City generally seems more advanced than Neiva City in part because Toyota City started addressing eco-related issues earlier. Toyota City is the headquarters of the Toyota Motor Corporation and it is inevitable that the company as well as the local government address these issues by introducing renewable energy and 
energy efficient systems such as HEMS. In contrast, Neiva City produces petroleum and natural gas. Accordingly, Toyota City focuses on sustainable energy and energy efficiency while Neiva City's eco-policy focuses more on the alleviation of traffic jams and the reduction of waste. This partly explains why Neiva City outperforms Toyota City in transportation and industry.

\section{Future Studies}

This is a preliminary pilot study and by no means conclusive. Therefore, some suggestions are made for future studies. First, some survey item questions may be replaced. For instance, with regard to transportation, we asked respondents about their willingness to buy environmentally friendly cars such as EVs/PHVs. Future studies may ask about the transportation systems such as Ha:mo in Toyota City and, "Tierra de Promisión" in Neiva City.

Also, the survey questions used in this study were based on the five themes in Toyota City's eco-policy. While Toyota City focuses on sustainable energy and energy efficiency, Neiva City's eco-policy focuses more on the alleviation of traffic jams and the reduction of waste arguably because Neiva City produces petroleum and natural gas, and thus may be less concerned about energy issues. Future studies may create questions oriented to Neiva City's perspectives

As the findings of this study show, the visibility of most of the items related to the five eco-policy themes was not high apart from some exceptions (e.g., transportation in Neiva). In addition to the cities' efforts to promote citizens' eco-awareness, we -scholars and relevant stakeholders- can help raise citizens' awareness of eco-policies through action research. In the current study, students at NUCB in Japan and University of Surcolombiana in Colombia not only learned and conducted research about their cities eco-policies but helped promote them to other citizens through the very act of conducting surveys. Some respondents confirmed that they learned about their cities' eco-policies by being surveyed. It is thus recommended that this type of study be continued to have a long lasting impact on citizens' awareness of eco-policies.

\section{Acknowledgements}

In support of this study, we are grateful to students at the Nagoya University of Commerce and Business in Japan and the Surcolombiana University in Colombia. We are particularly indebted to Jorge Enrique Sánchez Guarnizo, Carlos Eduardo Polanía Medina, Andrés Felipe Trujillo Castañeda, and Wendy Yolaine Quintero Trujillo. We would also like to thank Mr. Ezra Anton Greene for editing this paper.

\section{References}

[1] Toyota City. (2009). Summary of Action Plans towards an Environmental Model City. Retrieved on January 29, 2014: http://www.city.toyota.aichi.jp/division/an00/an06/1252190/0 2gaiyou.pdf

[2] Toyota City. (2014). Introduction about Toyota EcofulTown. Retrieved on September 4, 2014: http://toyota-ecofultown.com/english/

[3] Sennes, V., Gombert-Courvoisier, S., Ribeyre, F., and Felonneau, M. (2012). "Citizens' Environmental Awareness and Responsibility at Local Level." International Journal of Urban Sustainable Development 4(2): 186-197

[4] Ito, H. (2014). "Toyota as an environmental model city: Is its eco-policy recognized?” Journal of Sustainable Development 7(2): 70-78

[5] Ministerio de Transporte \& Ministerio de Hacienda y Crédito Público. (2013). Declaración de importancia estratégica del proyecto sistema estratégico de transporte público del municipio de Neiva. Retrieved on July 14, 2014 from https://pwh.dnp.gov.co/LinkClick.aspx?fileticket=f2TOSb14i GA\%3D\&tabid $=1656$

[6] Environmental Protection Agency. (2008). Reducing urban heat islands: Compendium of strategies. Washington DC: US Environmental Protection Agency.

[7] M. Young. (1989). The Technical Writer's Handbook. Mill Valley, CA: University Science.

[8] Alcaldía Municipal de Neiva. (2014a). 100 milliones de pesos seráninvertidos en el Parque Santander. Retrieved on August 27, 2014: http://www.alcaldianeiva.gov.co/index.php/ component/k2/item/2230-100-milliones-de-pesos-seran-invert idos-en-el-parquesantander

[9] Municipality of Neiva. (2014a). List of Beneficiaries for the Forestry Incentive. Technical Visit. Conducted on August 13, 2014.

[10] Gross, M. D. (1998). Smart house and home automation technologies. In Encyclopedia of Housing by W. van Vliet (ed). New York: Sage Publication.

[11] Automotive Technology. (2011). A new value created by the car battery: The key is how to use information about electric power. Automotive Technology November 2011.

[12] Toyota Motor Corporation. (2013). Toyota started sustainable plants towards improving environments in production. Retrieved on December 26, 2013: http://www.toyota.co.jp/jp/news/07/Jul/nt07_0707.html

[13] Toyota City. (2013). Toyota City Guide Book 2013. Toyota: Toyota City.

[14] Punches, J. (2004). Thinning: An important forest management tool. Oregon State University Extension Services. Retrieved on December 29, 2013: http://extension.oregonstate.edu/douglas/sites/default/files/doc uments/forestry/ ThinFact04.pdf

[15] Lowell, E. C., Dykstra, D. P., and Monserud, R. A. (2012). Evaluating effects of thinning on Wood Quality in Southeast Alaska. Western Journal of Applied Forestry 27(2): 72-83.

[16] Municipality of Neiva. (2014b). Deadline for tax discounts in protected environmental areas is complete. Retrieved on August 11, 2014: http://www.alcaldianeiva.gov.co/index.php/component/k2/ite $\mathrm{m} / 1428$-finaliza-plazo-de-descuentos-tributarios-en-areas-amb ientalmente-estrategicas 
[17] El Tiempo. (2013). Así funcionará la flota de los nuevos taxis eléctricos en Bogotá. Retrieved on September 20, 2014: http://www.byd.com.co/noticias

[18] El Tiempo. (2014). Toyota quiere implementar la recarga inalámbrica para hacer m:as versatiles su hídridos enchufables. Retrieved on September 20, 2014: www.motor.com.co/carros-ecologicos/ARTICULO-WEB-NE W_NOTA_INTERLOR-13500535.html 